\title{
INVESTIGATING FINANCIAL LITERACY TO IMPROVE FINANCIAL BEHAVIOUR AMONG BLACK CONSUMERS
}

\author{
Chantal Rootman* \\ Nelson Mandela Metropolitan University \\ chantal.rootman@nmmu.ac.za
}

Received: September 2014

\author{
Xolile Antoni\# \\ Nelson Mandela Metropolitan University \\ xolile.antoni2@nmmu.ac.za
}

Accepted: November 2014

\begin{abstract}
Due to South Africa's high unemployment rate and large uneducated population, consumers' low savings levels and high debt levels are of concern. Previous South African research in the domain of financial behaviour focused only on the population's debt and savings behaviour and the statistics thereof. There is little research on identifying solutions to poor debt and savings behaviour, as well as improvements in financial literacy and behaviour. As it is essential to improve consumers' financial literacy, increase their financial inclusion and change their financial behaviour to their financial benefit, it is important to investigate the relationships between these financial aspects. This exploratory study investigates aspects relating to financial literacy, financial inclusion and financial behaviour, specifically among black consumers in Nelson Mandela Bay. A total of 335 black consumers were respondents in an empirical investigation. The main results showed that saving and responsible spending behaviours can be improved as consumers' financial knowledge and inclusion increase. Based on the results, the article presents conclusions and recommendations regarding the financial education necessary to improve aspects relating to financial literacy, financial inclusion and financial behaviour.
\end{abstract}

Keywords

Financial education, financial literacy, financial inclusion and financial behaviour

*Prof C Rootman is an associate professor in the Department of Business Management, Nelson Mandela Metropolitan University, South Africa.

\#Mr X Antoni is a lecturer in the Department of Business Management, Nelson Mandela Metropolitan University, South Africa. 


\section{INTRODUCTION}

South Africa has a poor savings culture due to its high unemployment rate and a large uneducated population (Dempsey 2011:1). Unemployed citizens have no or low income levels, have often not received education on the need for saving and therefore the savings culture in South Africa is poor. FinMark Trust (2011:21) emphasises the poor saving culture in South African by stating that consumers are financially vulnerable because they do not save enough income for a later stage. The poor savings culture leads to South African consumers living in debt and using more credit than what they save (Maisel, n.d.: 2), putting doubt on how responsible consumers spend their financial resources. According to Ndumo (2011:1) almost $50 \%$ of South African consumers were in debt during 2010. This implies that South African consumers will possibly face difficulties in obtaining home loans or more debt (Ndumo 2011:1), due to their high level of already outstanding debt.

The poor savings and high debt situations result in South African consumers living in poor conditions. Without regular income and savings, with high debt levels and the inability to obtain more debt, as well as the increased probability of using no or unsuitable financial products, consumers live in poor conditions. According to Mashigo (2006:2), consumers living in poor conditions (in terms of their employment status, income levels, housing structures and financial activity) represent the largest segment of the South African population.

Cohen and Sebstad (2003:3) state that poor communities have access to credit in a way that is 'invisible' to the formal economy. This suggests that poor communities use informal financial systems to borrow funds from family, friends and moneylenders. The cash lenders used by poor communities are also known as 'loan sharks' and operate outside the formal economy of lending. They therefore are able to charge interest rates between $40 \%$ and $60 \%$ (Mashigo, 2006:4). These poor communities thus have less access to saving products and credit facilities from the formal economy (Maisel, n.d.:12). This may lead to poor communities being open to exploitation by lenders that lend them more money than they can afford to borrow (Mashigo, 2006:1). Poor communities have a poor credit record because they are not educated from an early age about bank accounts, the importance of saving and the possibility of using relevant financial products, as well as on how to use debt (Ndumo 2011:1), which possibly also leads to poor spending habits.

According to Hung, Parker and Yoong (2009:3), financial education refers to the process by which consumers' understanding of financial products, services and concepts is improved, which enables the consumers to be in positions to make informed financial decisions. Financial education is relevant to any consumers making financial decisions and this suggests that financial education is also important for poor communities attempting to make financial decisions. Therefore, financial education can be instrumental in improving the financial decisions of poor communities and thus is a way of ensuring that consumers improve their financial literacy levels to make informed financial decisions (FinMark Trust, 2011:21), for positive financial behaviour and outcomes.

According to Remund (2010:277), financial literacy relates to consumers' competency to manage their income. Hung et al. (2009:3) define financial literacy as consumers' ability to use their knowledge, skills and attitudes to manage income effectively to improve their financial well-being for the future. Consumers with high levels of financial literacy are knowledgeable and understand financial concepts like cash flows and inflation (OECD, 2013:26), and are able to manage their income on a day-to-day basis (Hilgert, Hogarth \& Beverly, 2003:320-321). 
Consumers with high levels of financial literacy are informed financial decision makers, have awareness of their personal financial issues and choices and have learned the basic financials skills such as spending, budgeting, borrowing and saving their income (Cohen \& Sebstad 2003:2; Tamaki, 2011:2).

This suggests that consumers with low levels of financial literacy might make poor financial decisions that result in financial problems. Consumers with low financial literacy levels might not, for example, budget, save, be able to borrow and repay debt, and therefore their financial inclusion levels are low. Consumers with lower levels of financial literacy indicate a lower level of financial inclusion in the formal economy (Tamaki, 2011:5). This means that many consumers in South Africa do not have access to banking institutions in the formal economy. Cohen and Nelson (2011:1) confirm that financial inclusion leads to an increased exposure to financial institutions, sophisticated financial products and services and an increased use of financial products and services by consumers. In addition, the lack of financial inclusion may lead to nonideal financial behaviour by consumers (The Banking Association South Africa, 2011:1). Roberts and Struwig (2011:15) also state that a lack of formal education may be a barrier to financial inclusion and positive financial behaviour, as consumers with no formal education rely on their families and social networks to access credit. It is evident that possible links exist between financial education, financial literacy, financial inclusion and financial behaviour.

\section{PROBLEM STATEMENT}

In a South African study by Roberts and Struwig (2011:vi-ix) it was evident that consumers have low levels of financial literacy, as $32 \%$ of the respondents did not understand financial concepts and $49 \%$ of the respondents were living beyond their means. According to Roberts, Struwig, Gordon, Viljoen and Wentzel (2012:33), South African consumers have low levels of financial knowledge on budgeting, saving products, the function of interest rates, life insurance, their credit profile as consumers, and credit agreements. Additionally, financial literacy levels also differ in terms of racial groups, as black consumers have the lowest financial knowledge levels when compared to consumers from the coloured, Indian and white population groups (Roberts et al., 2012:30). Black consumers also have the lowest percentages in terms of awareness and understanding of financial concepts (FinMark Trust, 2009). Since the majority of the South African population, and thus consumers, are black consumers, it is important that they make effective financial decisions as well as plan and reach their financial goals by being better educated and being financially literate. Research has shown that South African black consumers are the most dissatisfied with their financial situations compared to other races, and they are more likely to be financially unprepared (Roberts \& Struwig, 2011:12; Struwig, Roberts \& Gordon, 2013:34). Based on the above discussion of earlier related research, it is evident that extensive research is needed in the field of financial literacy in South Africa, especially among black consumers. It is important that research is conducted to determine how financial literacy among black consumers can be improved, for example through financial educational programmes. However, before a financial intervention (such as a financial education programme) can be designed for black consumers, a proper understanding of the concepts and relationships between financial literacy, financial inclusion and financial behaviour is needed. 


\section{OBJECTIVES OF THE STUDY}

The primary objective of study is to investigate the relationships between financial literacy, financial inclusion and financial behaviour, as applicable to the black community in Nelson Mandela Bay.

In order to attain the primary objective of the study, the secondary objectives of the study are formulated as follows:

- To investigate the concepts of financial literacy, financial inclusion, financial behaviour and financial education;

- To empirically investigate the relationships between financial literacy, financial inclusion and financial behaviour among black consumers; and

- To provide recommendations, based on the results, to financial education institutions and consumers.

\section{LITERATURE OVERVIEW}

In the following literature overview the concepts of financial education, financial literacy, financial inclusion and financial behaviour will be discussed. In addition, the purpose of financial education programmes will be highlighted.

\subsection{Financial education}

As previously mentioned, financial education refers to the process by which consumers' understanding of financial concepts, products and services is improved to participate financially in the formal economy. Financial education teaches consumers about financial concepts including spending, budgeting, saving and borrowing or debt management (Hassan et al., 2008:6; Sebstad, Cohen \& Stack, 2006; Orton, 2007:5). Hassan, Hendrie, Hobden and Musa (2008:4) state that financial education ensures that consumers improve their financial literacy and positively impact financial inclusion and financial behaviour. Financial education is thus a way of improving the levels of financial literacy, financial inclusion and ultimately the financial behaviour of consumers.

There are many benefits arising from financial education. Financial education can help consumers ensure that they save enough and have enough cash during retirement. It can also help consumers to handle the increasingly sophisticated formal economy (Hall 2008:15). Financial education increases consumers' awareness on issues such as a balanced budget, saving for their children's education and ensuring income at retirement (0ECD, 2006:2-3; Sebstad et al., 2006:8-9). Financial education can be provided by numerous institutions, such as schools, universities and consumers' workplaces. Mundy and Musoke (2011:54) state that it is important for children to learn about financial management practices at an early age. The reason for this is highlighted by Mundy and Musoke (2011:16): consumers develop their understanding of cash at an early age, and therefore schools should equip learners with the financial knowledge, understanding and skills to manage their income. Financial education programmes at school ensure that learners are responsible for their financial decisions, are informed about financial products and services and have appropriate attitudes about their spending behaviours (Mundy \& Musoke, 2011:54). In addition, employees need financial 
education in the workplace because of the financial provisions needed for retirement. A study by Kim and Garman (2003:10) found that employees' financial attitudes may change when they receive financial education at the workplace. Garman, Kim, Kratzer, Brunson and Joo (1999:83) indicated that financial education has an impact on employees' financial wellbeing. Garman et al. (1999:83) showed that a workplace financial education programme ensured that employees were more confident in making financial decisions, and their financial situations improved.

Financial education is important for improving consumers' levels of financial literacy so that they can plan their finances and realise their financial goals (Sebstad et al., 2006; Orton, 2007:5).

\subsection{Financial literacy through knowledge, skills and attitudes}

Financial literacy refers to consumers' financial knowledge, skills and attitudes, which translate into financial behaviours that enable consumers to meet their financial goals (Sebstad et al., 2006:6). Financial literacy thus refers to consumers' financial knowledge and skills to manage their income effectively with appropriate attitudes regarding financial matters. Empowered consumers, able to evaluate and use financial products, can be considered financially literate (Kefela, 2010:205). Consumers must have the necessary knowledge about financial aspects, skills and attitudes to manage their day-to-day expenses and to be able to choose financial products from different financial institutions (Kempson, 2009:4-6; Mundy \& Moseka, 2011:48; Roberts \& Struwig, 2011:2). These various authors clearly indicate that knowledge, skills and attitudes are indicators of financial literacy levels.

According to Shuttleworth (2011:98), financial knowledge refers to consumers' ability to understand financial information and use such knowledge to make informed and responsible financial decisions. Sebstad et al. (2006:10) state that financial knowledge refers to what consumers understand about financial concepts and financial products/services. According to Mundy and Musoke (2011:50), consumers should be knowledgeable about financial concepts such as budgeting, financial planning, savings, investments, choosing financial products from regulated financial institutions and the disadvantages of purchasing financial products from unregulated financial institutions. Consumers' financial knowledge will depend on their financial information-seeking abilities - in other words, whether they are willing to ask for financial advice, read financial sections of newspapers and learn about money management. However, financial knowledge should be translated into financial skills.

Mundy and Musoke (2011:15) refer to financial skills as the ability to apply financial knowledge to manage one's personal finances. Financial skills refer to consumers' ability to apply their financial knowledge in different contexts, as well as to manage and resolve their particular financial problems (Orton, 2007:7). Financial skills relate to consumers having the skills to plan, monitor, manage and resolve any financial problems they may experience (FSA 2005:14). Consumers need financial skills to deal with their lifecycle needs and unexpected emergencies without taking on more debt (Cohen \& Sebstad, 2003:8; 0ECD, 2006:1-2; Yilmaz, 2011:1). According to Delafrooz and Paim (2011:225), consumers with better financial skills have higher levels of saving behaviours and experience fewer financial problems. In other words, financial skills relate to the application of financial knowledge and the confidence to use this knowledge in a financial market to make financial decisions. William (2010:1-3) states that financial confidence relates to financial self-efficacy, which is consumers' perceived ability to manage their financial situations themselves. In other words, financial self-efficacy is consumers' perceived ability to use their financial knowledge to access and use financial products and 
services successfully (William, 2010:1-3). Higher levels of perceived financial self-efficacy or confidence often result in fewer financial problems being experienced by consumers (William, 2010:1-3).

Consumers' levels of financial confidence may be linked to their financial attitudes. Financial attitudes refer to the consumers' thoughts, feelings and opinions about financial issues (Sebstad et al. 2006:10). Previous research (Edwards, Allen \& Hayhoe, 2007; Shim, Barber, Card, Xiao \& Serido, 2010) shows that one's financial attitude mainly relates to how one thinks about money and credit. Financial attitudes usually influence consumers' decisions about the financial products/services they purchase (Botha du Preez, Goodall, Palframan \& Rossini, 2012:126). According to Potgieter (2013:5), the financial attitudes of consumers determine how they spend their cash, and, overall, financial attitudes determine specific financial behaviours (Koropp, Grichmik \& Kellermanns, 2013:115).

It is evident that consumers must have appropriate financial knowledge, financial skills and financial attitudes to manage their finances and be financially included in the market.

\subsection{Financial inclusion and financial behaviour}

Financial inclusion refers to the situation where consumers have access to financial products/services in a formal manner (The Banking Association South Africa, 2011:1; National Treasury, 2011:58; Tamaki, 2011:3), while financial exclusion refers to the situation where consumers do not have access to formal financial products/services. Consumers that are financially included may choose to use banking institutions and/or other financial institutions. (FinMark Trust, 2012:5). Financial inclusion also refers to access to, and affordability and usage of a range of financial products or services provided to consumers (Coovadia 2012:1). Financial inclusion is also a process of providing financial products/services to consumers in an affordable, convenient and simple manner (The Banking Association South Africa, n.d.). In this study, financial inclusion refers to a situation in which consumers have access to, can afford and regularly use financial products, and their financial needs are met. Improved levels of financial inclusion coupled by high levels of financial literacy may lead to positive changes in financial behaviour.

Financial behaviour refers to the actual financial decisions consumers make in the financial market, linked to their levels of saving, debt and spending. Regarding financial behaviour, the main focus is to understand how consumers make decisions and to identify the common mistakes that are made by consumers in the financial market (Botha, du Preez, Geach, Goodall, Palframan, Rossini \& Rabenowitz, 2013:125). Thus, financial behaviour describes the ways in which consumers make financial decisions and how consumers behave when they make these financial decisions (DeBondt, Forbes, Hamalianen \& Muradoglu, 2010:29). The financial decisions of consumers are influenced by their experiences in the financial market (and thus are linked to financial inclusion), as consumers with early experiences in the financial market tend to display effective financial behaviour (Sabri \& MacDonald, 2010:107). The above discussion shows that financial literacy and the resultant financial inclusion may lead to positive financial behaviour, and it is therefore important to consider the overall impact of financial education on financial behaviour. 


\subsection{The impact of financial education on financial behaviour}

The benefits of receiving financial education include consumers knowing what questions to ask when dealing with financial institutions, being able to handle complicated financial products and knowing to whom to complain when they are experiencing problems with financial institutions (Tamaki, 2011:2). The impact of receiving financial education may be indicated by increased savings, reduced debt and consumers reaching their financial goals. A study by Clark $(2005: 2-3)$ revealed that financial education can positively impact financial behaviour. In this study, students responded positively to financial education by saving on a regular basis, reconciling their bank accounts and tracking the repayment of their loans. Collis (2010:15) explains that financial education impacts financial behaviours positively and may motivate consumers to save more income and improve their credit ratings. This means that consumers who have a greater knowledge of personal finances tend to engage in effective financial behaviour (Sabri \& MacDonald, 2010:107). A study by Beale (2009:3) highlights that the benefits of financial education workshops are that consumers afterwards make informed financial decisions and use the financial strategies learned. The benefits of these financial education programmes are that they are designed to meet the needs of rural communities and therefore engage directly with the problems faced by those communities (FinMark Trust, 2004:10).

In contrast, a lack of financial education exposes consumers to financial problems such as the financial products that are unethically marketed and consumers defaulting on payments due to pressure on their income (Aziz, 2005:3; MasterCard Foundation, 2011:11). Consumers who do not have access to financial education usually lack the financial skills to take advantage of financial products or services to improve their financial situation (Yoong, 2010:5). Low levels of financial literacy because of limited financial education may be a barrier to financial inclusion. Consumers may for instance not open a bank account because they do not know how to open it and/or do not understand the benefits of having a bank account (Yoong, 2010:6).

Nene (2009:3) observes that low levels of financial literacy may be a barrier to savings behaviour. Consumers with low levels of financial literacy are usually less savings-oriented, borrow more and are more likely to overspend their income (Mandell \& Klein, 2009:19). According to Grubman, Bollerud and Holland (2011), consumers' overspending is one of the major financial problems facing consumers. The problems include addictive spending, poor budgeting and incurring too much debt. Hearth, Kurtz and Boone (2006:74) argue that consumers overspend usually because they do not keep track of their expenses, they have access to credit cards and/or do not have any financial goals. In addition, Falahati and Paim (2011:1765) indicate that the financial problems experienced by consumers result from poor financial behaviours, such as using debt excessively.

Maisel (n.d.:9) highlights that the low savings rate and the high incidence of debt in South Africa suggest that the financial behaviours of consumers need to change. Financial education may, especially for the large, attractive black consumer market in South Africa, ensure high levels of financial literacy, more access to financial products/services (higher financial inclusion) and ultimately more appropriate financial behaviour. Therefore, for the purpose of this study, based on the literature discussion above, black consumers' perceptions on financial literacy (including financial knowledge, financial skills and financial attitude), financial inclusion and financial behaviour will be investigated in the empirical investigation. 


\section{RESEARCH HYPOTHESES}

The research objectives and literature overview were used to formulate the following hypotheses:

$\mathrm{H}_{1.1}$ : There is a relationship between financial knowledge and financial inclusion.

$\mathrm{H}_{1.2}$ : There is a relationship between financial skills and financial inclusion.

$\mathrm{H}_{1.3}$ : There is a relationship between financial attitudes and financial inclusion.

$\mathrm{H}_{2.1}$ : There is a relationship between financial inclusion and financial behaviour.

\section{RESEARCH METHODOLOGY}

\subsection{Population and sampling method}

The study used a quantitative research approach: hypotheses were tested by way of a numerical measuring instrument (Zikmund, Babin, Carr \& Griffin, 2010:134) to ultimately determine the influence of the identified variables on the financial behaviour of black consumers, through statistical analyses. The population for this study was black consumers in Nelson Mandela Bay in the Eastern Cape, South Africa. This study made use of non-probability sampling because of the fact that probability sampling requires a sample frame for a study, and no appropriate sample frame of black consumers was available. The study adopted convenient and snowball sampling techniques to choose a sample for the study. Convenient sampling refers to selecting a sample based on availability and convenience (Gray, 2009:153; Zikmund et al., 2010:396). Snowball sampling refers to selecting a number of sample members from the population who in turn identify other sample members from the population (Gray, 2009:153; Zikmund et al., 2010:398). Thus, black consumers were chosen on the basis of convenience, meaning that the respondents were consumers that the researcher could easily reach. Other respondents for the study were members referred to the researchers by family, friends, colleagues and respondents. To ensure no bias, fieldworkers, adequately informed about the research and proper data collection procedure, were also used during the data collection process.

\subsection{Measuring instrument for data collection and data analysis}

A questionnaire consisting of mainly closed-ended questions was used to collect the data from the respondents. The self-developed, structured questionnaire, based on the literature, was divided in two sections. Section A gathered respondents' demographical data, including respondents' age, gender, education level and ethnic group. Section B consisted of 59 items in the format of a five-point Likert scale ( 1 = strongly disagree to 5 strongly agree) and gathered respondents' perceptions on aspects relating to their financial literacy (financial knowledge, financial skills and financial attitudes), financial inclusion (intervening variable) and financial behaviour (dependent variable). Content validity of the measuring instrument was ensured, as experts in the fields of financial management and financial planning assisted with the questionnaire design (Zikmund et al., 2010:307).

The computer software programmes Microsoft Excel and Statistica were used to perform the study's data analysis in five steps. Descriptive statistics, such as means and standard 
deviations, were calculated to describe and summarise the characteristics of the data (Zikmund, Babin, Carr \& Griffin, 2012:410), specifically to summarise the demographic data of respondents. An exploratory factor analysis (EFA) was performed, and loadings of at least 0.50 were considered valid (Hair, Black, Babin \& Anderson, 2010:117). The EFA was performed to ensure the construct validity of the measuring instrument (Wiid \& Diggines, 2013:241). Thereafter, Cronbach's alpha coefficients were calculated to test the internal reliability of the measuring instrument, and a score of at least 0.7 was used as the cut-off score (Blaikie, 2003:221; Wiid \& Diggines, 2013:238). Pearson's correlation coefficients ( $r$ ) were calculated to show the correlations or links between the different variables (Wiid \& Diggines, 2013:283; Zikmund et al., 2010:559). Finally, multiple regression analyses were used to test for significant relationships between the variables (Zikmund et al., 2010:584).

\section{EMPIRICAL RESULTS}

\subsection{Questionnaire responses and descriptive statistics}

Black consumers were asked to voluntarily participate, and of the 500 questionnaires distributed, 400 questionnaires were completed by respondents, of which 335 questionnaires were found to be suitable for the quantitative statistical analysis. This means that a response rate of $67.00 \%$ was achieved for this study. The remaining questionnaires (65) were not suitable for statistical data analysis as they either had missing data or had more than one marked response per item.

The majority of the respondents were females (53.73\%) between the ages of 30 to 39 years $(37.31 \%)$ and between the ages of 40 to 49 years $(30.75 \%)$. The majority of respondents were never married (54.63), as opposed to $25.97 \%$ of the respondents who were married. In terms of qualification levels, $40 \%$ of the respondents had a matric qualification (Grade 12); however, $20 \%$ of the respondents had a postgraduate qualification. Of the respondents, 163 respondents (48.65\%) had an income level of above R7 000, 115 respondents (34.33\%) had an income level of between R3 000 and R7 000 and 56 respondents (16.72\%) had an income level of between R0 and R3 000 .

\subsection{Validity and reliability results}

The EFA showed 47 items that loaded onto seven different factors. As mentioned, any items that loaded insufficiently onto a factor that is below 0.5 , were removed for further analysis to ensure the construct validity of the measuring instrument. The EFA factor loadings can be viewed in Annexure A. From the loadings of the items onto the factors, it is evident that sufficient evidence of construct validity was provided, as a sufficient number of items with loadings above 0.5 loaded onto the factors.

Consistent with the literature and as stated in the developed hypotheses, relevant items loaded onto two factors, labelled financial knowledge and financial skills respectively. Factor one was named financial knowledge, as nine out of the 11 items expected to measure the factor loaded significantly. The second factor was named financial skills, as seven out of the 12 items expected to measure this factor loaded significantly together. However, based on the items which loaded onto each factor, certain factors were renamed. Factor three was named financial confidence. As mentioned in the literature review, financial confidence is considered an aspect 
of one's financial attitude. Considering the significant loading of four of the 11 items developed to measure financial attitudes, and the fact that all these items relate to respondents' financial confidence levels, this factor was renamed financial confidence. An additional factor emerged, as five items initially developed to measure financial attitudes loaded significantly together. This factor was named financial information seeking, as items relate to respondents' efforts to seek financial information and advice. In other words, from the items developed to measure the initial proposed financial attitudes factor, two factors emerged: financial confidence and financial information seeking. From the $\varepsilon F A$, items developed to measure the initial intervening and dependent variables loaded onto three separate factors. These were named, based on the items which loaded, low financial inclusion (five items loaded), banking and savings behaviour (nine items loaded) and responsible spending behaviour (eight items loaded) respectively. The literature revealed that one's financial behaviour relates to various financial actions, including one's efforts to bank and save as well as spend financial resources. Therefore, the resultant factor loadings were regarded as acceptable and were used in further analyses.

Following the EFA, factors one to five (financial knowledge, financial skills, financial confidence, financial information seeking and low financial inclusion) represent the independent variables. Factor six (banking and savings behaviour) represents the intervening variable, while factor seven (responsible spending behaviour) represents the dependent variable. Based on the above EFA results, the revised theoretical framework and revised hypotheses that were tested in further analyses are presented in FIGURE 1.

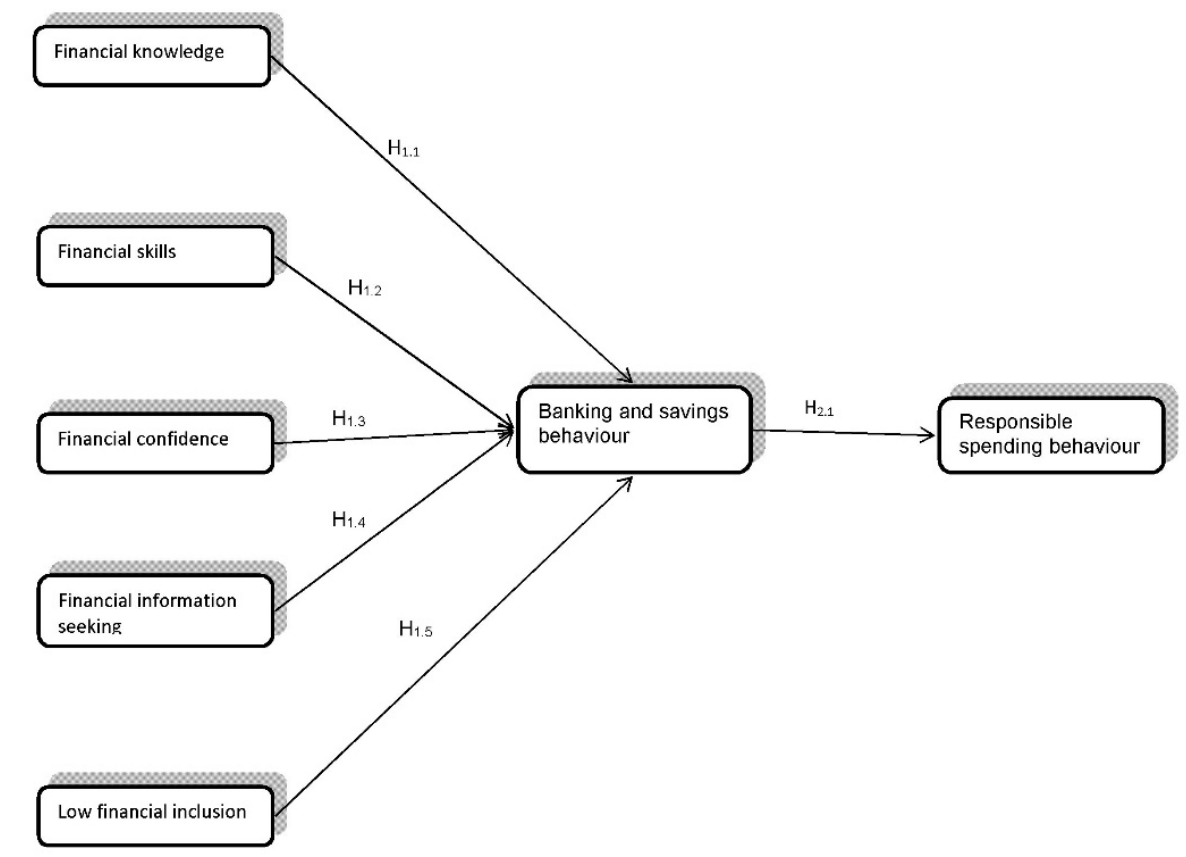

\section{FIGURE 1: Adapted theoretical framework}

Source: Researchers' own construct following the EFA results 
Therefore, based on the EFA results, the initially set hypotheses were rephrased for further analyses as follows:

$\mathrm{H}_{1.1}$ : There is a relationship between financial knowledge and banking and savings behaviour.

$\mathrm{H}_{1.2}$ : There is a relationship between financial skills and banking and savings behaviour.

$\mathrm{H}_{1.3}$ : There is a relationship between financial confidence and banking and savings behaviour.

$\mathrm{H}_{1.4}$ : There is a relationship between financial information seeking and banking and savings behaviour.

$\mathrm{H}_{1.5}$ : $\quad$ There is a relationship between low financial inclusion and banking and savings behaviour.

$\mathrm{H}_{2.1}$ : $\quad$ There is a relationship between banking and savings behaviour and responsible spending behaviour.

TABLE I presents the Cronbach's Alpha coefficients from the reliability analysis.

TABLE 1: Inter-item correlation and reliability of the measuring instrument

\begin{tabular}{lc}
\hline Variables & Cronbach's Alpha \\
\hline Financial knowledge & 0.91 \\
Financial skills & 0.87 \\
Financial confidence & 0.81 \\
Financial information seeking & 0.72 \\
Low financial inclusion & 0.78 \\
Banking and savings behaviour & 0.85 \\
Responsible spending behaviour & 0.83 \\
\hline
\end{tabular}

Source: Calculated from survey reliability results

As evident, all factors returned a Cronbach's alpha higher than the recommended 0.7 (Blaikie (2003:221). Based on the results shown in TABLE 1, the measuring instrument of this study was regarded as reliable.

\subsection{Relationship results - Pearson's r and multiple regression analysis}

The Pearson's $r$ calculations indicated that the strongest correlation was between financial confidence and financial information seeking $(r=0.956)$. The weakest correlation was between financial skills and responsible spending behaviour $(r=0.135)$. Pearson's $r$ also showed that each independent variable (financial knowledge, financial skills, financial confidence, financial information seeking, and low financial inclusion) has a significant correlation with both the intervening variable, banking and savings behaviour $(r=0.689, r=0.376, r=0.667, r=0.667$, and $r=-0.043$ respectively), and the dependent variable, responsible spending behaviour $(r=479$, $r=0.135, r=0.534, r=0.526$, and $r=-0.164$ respectively). As expected, low financial inclusion 
has negative correlations with both banking and savings behaviour and responsible spending behaviour. This means that as respondents' low financial inclusion are more pertinent (thus they have less access to financial products/services) their banking and savings behaviour, as well as their responsible spending behaviour decreases. In other words, consumers with low levels of financial inclusion (low access to formal financial products/services), also have low levels of both savings and responsible spending habits. In addition, the intervening variable banking and savings behaviour also has a significant correlation with the dependent variable responsible spending behaviour $(r=0.585)$. All correlations were significant at the $5 \%$ significance level.

Multiple regression analyses were performed in three stages to test relationships between the variables. TABLE 2 provides the results of the first stage of the multiple regression analyses, which tested the relationships between the independent variables and the intervening variable.

TABLE 2: Multiple regression analysis results for the influence of the independent variables on the intervening variable banking and savings behaviour

\begin{tabular}{lcc}
\hline & & $\mathrm{R}^{2}=0.61$ \\
\hline Independent variables & Regression coefficient & $p$-value \\
Financial knowledge & 0.41 & $0.000^{\star}$ \\
Financial skills & 0.21 & $0.000^{\star}$ \\
Financial confidence & 0.12 & 0.339 \\
Financial information seeking & 0.24 & 0.060 \\
Low financial inclusion & -0.11 & $0.023^{*}$ \\
\hline
\end{tabular}

Source: Calculated from survey multiple regression results - Phase 1

From TABLE 2 it is evident that the independent variables financial knowledge and financial skills have significant positive relationships $(p<.05)$ with banking and savings behaviour (the intervening variable), while low financial inclusion shows, as expected, has a significant negative relationship $(p<.05)$ with banking and savings behaviour. This implies that increased financial knowledge and financial skills lead to increased banking and savings behaviour. Consumers demonstrating high levels of financial knowledge, financial skills and financial inclusion or access will demonstrate positive banking and savings behaviour. In addition, if decreases occur in one's low financial inclusion status (thus one's access to financial products/services increases), one's banking and savings behaviour improves. The significance level is set at .05 , which means that a $5 \%$ probability error is accepted (Cohen, Manion \& Morrison, 2007:519). In total, the independent variables explain or predict $61 \%$ of the variance in the intervening variable (banking and savings behaviour), which indicates the percentage change in the intervening variable caused by all the independent variables (Zikmund et al., 2010:586).

TABLE 3 provides the results of the second stage of the multiple regression analyses, which tested the relationship between the intervening variable and the dependent variable. 
TABLE 3: Multiple regression analysis results for the influence of the intervening variable on the dependent variable responsible spending behaviour

\begin{tabular}{lcc}
\hline & & $\mathrm{R}^{2}=0.34$ \\
\hline Intervening variable & Regression coefficient & $p$-value \\
Banking and savings behaviour & 0.59 & $0.000 *$ \\
\hline
\end{tabular}

Source: Calculated from survey multiple regression results - Phase 2

TABLE 3 shows a positive relationship between the intervening (banking and savings behaviour) and dependent (responsible spending behaviour) variables. This means that consumers who have high levels of banking and savings behaviour will demonstrate more responsible spending behaviour. The intervening variable (banking and savings behaviour) has a statistically significant relationship with the dependent variable (responsible spending behaviour). Furthermore, the intervening variable (banking and savings behaviour) explains or predicts $34 \%$ of the variance in the dependent variable (responsible spending behaviour).

As this study aims to consider the influence of financial literacy aspects on financial behaviour, and the EFA revealed responsible spending behaviour as a specific component of financial behaviour, a third multiple regression analysis was performed. TABLE 4 illustrates the direct relationships between the independent variables (financial knowledge, financial skills, financial confidence, financial information seeking and low financial inclusion) and the dependent variable (responsible spending behaviour).

TABLE 4: Multiple regression analysis results for the influence of the independent variables on the dependent variable responsible spending behaviour

\begin{tabular}{lcc}
\hline & & $\mathrm{R}^{2}=0.34$ \\
\hline Independent variables & Regression coefficient & $p$-value \\
Financial knowledge & 0.24 & $0.000^{\star}$ \\
Financial skills & 0.03 & 0.652 \\
Financial confidence & 0.39 & $0.016^{\star}$ \\
Financial information seeking & -0.01 & 0.934 \\
Low financial inclusion & -0.15 & $0.018^{\star}$ \\
\hline
\end{tabular}

Source: Calculated from survey multiple regression results - Phase 3

TABLE 4 shows significant positive relationships between two independent variables (financial knowledge and financial confidence) and the dependent variable (responsible spending behaviour). This shows that as financial knowledge and financial confidence increase, consumers' responsible spending behaviour will improve. Furthermore, only low financial access had a significant negative relationship with responsible spending behaviour. This confirms that if low financial inclusion increases (limited financial access becomes more prevalent) responsible spending will decrease. This means that high levels of financial knowledge, financial confidence and financial inclusion translate into improved responsible spending behaviour. The variance explained is $34 \%$, which means that the independent variables explain or predict $34 \%$ of the variance in the dependent variable. 
The multiple regression analyses indicate that it is important to notice the difference in results when considering the relationships between the independent variables and the intervening variable, as compared to the relationships between the independent variables and the dependent variable. The differences in results are the following:

- Financial skills has a significant positive relationship with banking and savings behaviour, but not with responsible spending behaviour, and

- Financial confidence has a significant positive relationship with responsible spending behaviour, but not with banking and savings behaviour.

This suggests that financial skills are particularly important in improving one's banking and savings behaviour, whereas financial confidence is of the essence when one is aiming to spend one's financial resources appropriately.

Therefore, all of the revised hypotheses were accepted and none rejected as it was found that there were relationships between each of the independent variables (financial knowledge, financial skills, financial confidence, information seeking and low financial inclusion) and the intervening variable (banking and savings behaviour) $\left(\mathrm{H}_{1.1}, \mathrm{H}_{1.2}, \mathrm{H}_{1.3}, \mathrm{H}_{1.4}\right.$ and $\mathrm{H}_{1.5}$ accepted) as well as between the intervening variable and the dependent variable (responsible spending behaviour) $\left(\mathrm{H}_{2.1}\right.$ accepted). However, the significance and direction of the various relationships differ, as explained through the results of the multiple regression analyses.

\section{CONCLUSIONS AND RECOMMENDATIONS}

It is evident that financial behaviour consists of various components, including banking and savings behaviour and spending behaviour. From the sample of black consumers, it became apparent that specific financial aspects are important for each of these financial behaviour outcomes. Financial education institutions should focus on certain financial terms, concepts and aspects when (1) they provide financial education specifically with the aim of increasing consumers' participation in banking activities (for example, opening bank accounts), or (2) when educating consumers on spending patterns and concerns.

The main conclusions from the empirical investigation are:

- In many instances, consumers first need to improve their banking and savings behaviour to ensure that their spending behaviour become more responsible;

- To increase consumers' banking participation and improve their levels of saving, financial knowledge, financial skills and financial inclusion need to improve; and

- To increase responsible spending habits, consumers' financial knowledge, financial confidence and financial inclusion need to improve.

Therefore, it is evident that financial education institutions should focus on increasing black consumers' financial knowledge, skills, confidence and inclusion. The recommendations provided are therefore linked to these financial aspects.

Specifically, to increase black consumers' financial knowledge, financial education institutions (including banks, financial advisors/planners and universities/colleges, among other entities) should focus on educating consumers on how to open a bank account, on the limits of credit facilities as well as the available products linked to investments, insurance and retirement planning. In addition, consumers should be educated on how interest rates influence financial 
products and outcomes. In order to increase black consumers' financial skills, financial education institutions should teach consumers how to compare financial products/services as well as different financial service providers, and also how follow a budget, keep record of income and expenses, and keep extra finances for emergencies. With regard to increasing black consumers' financial confidence, consumers should be informed about relevant and trusted sources of financial advice, for example financial institutions operating in their areas of residence. Also when considering financial inclusion, financial education institutions should teach consumers about the sources of financial advice that are available, and how or where to access these sources. It can be argued that better sources of financial advice, for example, well-informed and educated financial advisors, financial planners and bank employees, could lead to higher levels of financial inclusion, as consumers will be better informed and advised about appropriate financial products/services and institutions. Another way to increase financial inclusion is to ensure consumers' easy physical access to financial services. For example, banks should aim to reduce travelling distance for consumers by increasing the presence of ATMs and branches, if possible, close to the living and working areas of consumers. In addition, financial institutions should encourage the use of cell phones to conduct banking transactions.

In financial educational programmes, to instil positive financial behaviour, consumers should be told about the importance and benefits of saving and how to go about spending income wisely. Regarding banking and savings behaviour, it is recommended that financial institutions provide incentives for consumers to save, for example by positively adjusting interest rates on savings products. This will encourage consumers to keep positive balances in their bank accounts as a form of saving or to open separate savings accounts. Financial institutions could offer personalised financial savings products at lower fees, to incentivise consumers in order to improve savings. More specifically with regard to responsible spending behaviour, the emphasis of financial educational programmes should be on how to evaluate potential purchases, keep record of expenses and monitor spending. As a whole, the timing (when) and place (where) financial educational programmes are offered should be convenient for consumers. For example, free-entry financial educational programmes in the form of workshops, seminars and/or short 'help/advice' sessions could be offered at locations convenient to consumers (e.g. close to their areas of residence). The implementation of these recommendations might lead to financial benefits for consumers.

\section{LIMITATIONS AND FUTURE RESEARCH}

Some limitations, such as the convenience and snowball sampling techniques used, were evident in this study. This exploratory study was directed at black consumers in the Nelson Mandela Bay area and this means that the results are not readily generalisable. Consequently, a more geographically diverse sample should be drawn for future research.

The results of this study have provided insight into black consumers' financial literacy, financial inclusion and financial behaviour, based on their own perceptions thereof. The study provided suggestions and recommendations to financial education institutions on areas to focus on in order to ensure higher levels of financial literacy (as linked to financial knowledge, financial skills, and financial confidence) as well as financial inclusion and financial behaviour (in terms of banking and savings behaviour and responsible spending behaviour) among black consumers. 
As a result, the financial inclusion of black consumers might increase and ultimately their financial behaviour in terms of banking and saving and responsible spending might improve.

To conclude, the study is valuable in that it showed which financial aspects financial educational programmes and institutions should focus on, regarding financial literacy and financial inclusion, in order to improve banking and savings behaviour as well as responsible spending behaviour. The implementation of this study's recommendations will benefit consumers' personal financial planning and contribute to consumers achieving their financial goals, which may ultimately benefit the South African economy.

\section{LIST OF REFERENCES}

Aziz, Z.A. (2005). Enhancing financial literacy for sustained economic prosperity. Proceedings of the Citigroup-INSEAD Financial Education Summit, 12 December, Kuala Lumpur, Malaysia.

Beale, R. (2009). Providing financial education to the community: Business students' contribution. Proceedings of the Allied Academies International Conference, 12(1), pp. 1-4, 8-10 April, New Orleans, LA, USA.

Blaikie, N. (2003). Analyzing quantitative data. London, England: Sage.

Botha, M., du Preez, L., Goodall, B., Palframan, J. \& Rossini, L. (2012). Fundamentals of financial Planning. Durban: LexisNexis.

Botha, M., du Preez, L., Goodall, B., Palframan, J. \& Rossini, L. (2013). Fundamentals of financial Planning. Durban: LexisNexis.

Clarke, P. (2005). A path to financial literacy: Potential impact of a personal finance course. Journal of the Academy of Business Education, 6(1), pp. 1-4.

Cohen, L., Manion, L. \& Morrison, K. (2007). Research methods in education, $6^{\text {th }}$ edition. USA: Routledge.

Cohen, M. \& Nelson, C. (2011). Financial literacy: A step for the clients towards financial inclusions. Proceedings of the Global Mirocredit Summit, 14-17 November, Valladolid, Spain.

Cohen, M. \& Sebstad, J. (2003). Financial education for the poor. Microfinance Opportunities, Washington, D.C., USA. (Working paper 1).

Collis, J.M. (2010). Effects of mandatory financial education on low income clients. Focus, 27(1), pp. $13-18$.

DeBondt, W., Forbes, W., Hamalainen, P. \& Muradoglu, YG. (2010). What can behavioural finance teach us about finance? Qualitative Research in Financial Markets, 2(1), p. 29.

Delafrooz, N. \& Paim, L.H. (2011). Determinants of savings behaviour and financial problems among employees in Malaysia. Australian Journal of Basic and Applied Science, 5(7), pp. 222-228.

Dempsey, P. (2011). Family debt crisis: 5 lessons from the Eurozone. Association for Savings and Investment South Africa (ASISA). Available:

http://itinews.co.za/print.aspx?type $=2$ \&itemid $=3270$ E0FD-3FA8-45AB-906B-34D5CC155B2C

(Accessed l September 2014).

Edwards, R., Allen, M.W. \& Hayhoe, C.R. (2007). Financial attitudes and family communication about students' finances: The role of sex differences. Communication Reports, 20(2), pp.90-100. 
Falahati, L. \& Paim, L.H. (2011). Gender differences in financial well-being among college students. Australian Journal of Basic and Applied Sciences, 5(9), pp. 1765-1776.

FinMark Trust. (2004). Financial literacy scoping study and strategy projects. Final Report. ECl Africa, Woodmead, South Africa.

FinMark Trust. (2009). SA needs more financial education. Available: http://www.finmark.org.za/wpcontent/uploads/pubs/FinMark-AR-2009.pdf (Accessed 19 June 2012).

FinMark Trust. (2011). Annual report 2011. Available:

http://www.housingfinanceafrica.org/document/finmark-trusts-annual-report-2011/ (Accessed l June 2012).

FinMark Trust. (2012). Survey highlights: FinScope South Africa. Available: http://www.finmark.org.za/wpcontent/uploads/pubs/FinScope_SA_Booklet_2012.pdf (Accessed 31 July 2013).

FSA. (2005). Measuring financial capability: An exploratory study. Available: http://www.fsa.gov.uk/static/pubs/consumer-research/crpr37.pdf (Accessed 20 April 2013).

Garman, E.T., Kim, J., Kratzer, C.Y., Brunson, B.H. \& Joo, S. (1999). Workplace financial education improves personal financial wellness. Association for Financial Counselling and Planning Education, 10(1), pp. 79-88.

Gray, D.E. (2009). Doing research in the real world, $2^{\text {nd }}$ edition. Los Angeles: Sage.

Grubman, J., Bollerud, K. \& Holland, C.R. (2011). Motivating and helping the overspending client: A stage-of-change model. Journal of Financial Planning, 24(3), pp. 60.

Hair, J.F., Black, W. C., Babin, B.J. \& Anderson, R.E. 2010. Multivariate data analysis, th edition. London: Pearson.

Hall, K. (2008). The importance of financial literacy. Sydney: Reserve Bank of Australia.

Hassan, N., Hendrie, S., Hobden, T. \& Musa, 0. (2008). Delivering money advice in South Africa: Study into the provision of money advice to low-income persons. Johannesburg: Genesis Analytics.

Hearth, D., Kurtz, D.L. \& Boone, L.E. (2006). Planning your financial future, $4^{\text {th }}$ edition. Asia: Thompson.

Hilgert, M. A., Hogarth, J. M. \& Beverly, S.G. (2003). Household Financial Management: The Connection between knowledge and behavior. Federal Reserve Bulletin, 89(7), pp. 309-322.

Hung, A.A., Parker, A.M. \& Yoong, J.Y. (2009). Defining and measuring financial literacy. RAND Corporation, USA. (Working Paper Series WR-708).

Kefela, G.T. (2010). Promoting access to finance by empowering consumers: Financial literacy in the developing countries. Educational Research and Reviews, 5(5), pp. 205-212.

Kempson, દ. (2009). Framework for the development of financial literacy baseline surveys: A first international comparative analysis. Available: www.oecd.org/dataoecd/4/29/45153314.pdf (Accessed 24 September 2012). (0ECD Working papers).

Kim, J. \& Garman, T. (2003). Financial education and advice changes worker attitude and behaviours. Journal of Compensation and Benefits, September/0ctober, pp. 7-13.

Koropp, C., Grichnik, D. \& Kellermanns, F. 2013. Financial attitudes in family firms: The moderating role of family commitment. Journal of Small Business Management, 51(1), pp. 114-137. 
Lapp, W.M. (2010). The missing link: Financial self-efficacy's critical role in financial capability. EARN Research Institute, White paper.

Maisel, C. (n.d.). South Africa is a buy now, pay later society: How do we change this to save now and pay later culture. Available: http://www.soulcity.org.za/projects/soul-buddyz/soul-buddyz-series3 /literature-review/financial-literacy-and-management (Accessed 3 June 2012).

Mandell, L. \& Klein, L.S. (2009). The impact of financial literacy education on subsequent financial behaviour. Association for Financial Counselling and Planning Education, 20(1), pp. 15-24.

Mashigo, P. (2006). The debt spiral in the poor household in South Africa. International Indigenous Journal. Available: http://www.indigenousjournal.com/IIJEASVollllss IMashigo.pdf (Accessed 19 July 2012).

MasterCard Foundation. (2011). Taking stock: Financial education initiatives for the poor.

MasterCard Foundation, Toronto, Ontario, Canada.

Mundy, S. \& Moseke, C. (2011). Towards an effective framework for financial literacy and financial protection in Uganda. Available: http://www.microfinancegateway.org/gm/document-

1.9.55544/Framework_for_Financial_Literacy_and_Financial_Consumer_Protection_in_Uganda.pdf (Accessed 20 August 2012).

Ndumo, P. (2011). From debt to riches: Steps to financial success. Johannesburg: Ultra Litho.

Nene, N. (2009). Speech at the launch of savings month. South African Savings Institute, Ministry: Finance, South Africa.

OECD. (2013). Financial literacy and inclusion: Resu/t of OECD/INFE survey across countries and by gender. Available: http://www.oecd.org/daf/fin/financial-

education/TrustFund2013_0ECD_INFE_Fin_Lit_and_Incl_SurveyResults_by_Country_and_Gender.pdf (Accessed 5 December 2014).

0ECD. (2006). The importance of financial education. Available:

http://www.oecd.org/finance/financial-education/37087833.pdf (Accessed 6 June 2012).

Orton, L. (2007). Financial literacy: Lessons from international experience. Canadian Policy Research Networks Research report, Ottawa, Ontario, Canada.

Potgieter, K. 2013. Change your client's attitude: Change their retirement. The Financial Planner, 27, pp. 14.

Remund, D.L. (2010). Financial literacy explicated: The case for a clearer definition in an increasing complex economy. Journal of Consumer Affairs, 4(2), pp. 267-293.

Roberts, R. \& Struwig, J. (2011). Financial literacy in South Africa: Results of an OECD/INFE pilot study. Human Science Research Council, Pretoria, South Africa.

Roberts, B., Struwig, J., Gordon, S., Viljoen, J. \& Wentzel, M. (2012). Financial literacy in South Africa: Results of a national baseline survey. Available:

ftp://ftp.fsb.co.za/public/Consumer\%20Education/Financial\%20Literacy\%20Booklet\%202012.pdf (Accessed 2 May 2013).

Sabri, M.F. \& McDonald, M. (2010). Savings behaviour and financial problems among college students: The role of financial literacy in Malaysia. Cross-Cultural Communication, 6(3), pp. 103-110.

Sebstad, J., Cohen, M. \& Stack, K. (2006). Assessing the outcomes of financial education. Microfinance Opportunities, Washington, D.C., USA. (Working paper 3). 
Shim, S., Barber, B.L., Card, N.A., Xiao, J.J. \& Serido, J. (2010). Financial socialization of first-year college students: The roles of parents, work and education. Journal of Youth and Adolescence, 39 , pp.1457-1470.

Shuttleworth. (2011). A financial literacy education framework for non-financial individual in organisation. Pretoria: Unisa Press.

Struwig, J., Roberts, B. \& Gordon, S. (2013). Financial literacy in South Africa: 2013 Report. Available: https://www.mylifemymoney.co.za/Resources/Research\%20Documents/Financial\%20Literacy\%20Re port\%202013.pdf (Accessed 27 August 2013).

Tamaki, R. (2011). Opening Remarks. OCED-FSB Conference on Financial Literacy: Financial Education for all, 27-28 0ctober, Cape Town, South Africa.

The Banking Association South Africa. (2011). Democratising financial services. Available:

http://www.banking.org.za/index.php/our-industry/financial-inclusion/ (Accessed 28 August 2013).

The Banking Association South Africa. (n.d.). Working definition of financial inclusion. Available: http://www.banking.org.za/index.php/our-industry/financial-inclusion/working-definition-offinancial-inclusion/ (Accessed 28 August 2013).

Wiid, J. \& Diggines, C. (2013). Marketing research, $2^{\text {nd }}$ edition. Cape Town: Juta.

William, M. L. (2010). The missing link: Financial self-efficacy's critical role in financial capability. Available: http://www.earn.org/static/uploads/files/Missing_Link_Financial_SelfEfficacy_Critical_Role_in_Financial_Capability.pdf (Accessed 5 December 2014).

Yilmaz, H. (2011). Improving financial literacy: The US experience. International Journal of Business and Social Science, 2(11), pp. 65-72.

Yoong, J. (2010). Behavioural economics and financial education. 0ECD-Bank of Italy symposium on financial literacy: Improving Financial Education Efficiency, 9 June, Rome, Italy.

Zikmund, W. G., Babin, B. J., Carr, J. C. \& Griffin, M. (2010). Business research methods, $8^{\text {th }}$ edition. Montreal: South-Western.

Zikmund, W.G., Babin, B.J., Carr, J.C. \& Griffin, M. (2012). Business research methods, $9^{\text {th }}$ edition. Mason, $\mathrm{OH}$ : Cengage Learning. 


\section{ANNEXURE: EXPLORATORY FACTOR ANALYSIS TABLES}

\begin{tabular}{|c|c|c|c|c|}
\hline \multirow{2}{*}{ Items } & Factor 1 & Factor 2 & Factor 3 & Factor 4 \\
\hline & Financial knowledge & Financial skills & Financial confidence & Financial information seeking \\
\hline Bl.1 & 0.785229 & -0.001712 & 0.262308 & -0.099621 \\
\hline Bl.3 & 0.542873 & 0.329858 & 0.009530 & -0.058055 \\
\hline Bl.7 & 0.702263 & 0.159016 & 0.057595 & 0.026853 \\
\hline B1.8 & 0.701283 & 0.151353 & 0.172325 & 0.031854 \\
\hline B1.9 & 0.816709 & -0.008954 & 0.168314 & -0.080306 \\
\hline B1.10 & 0.762073 & 0.050325 & 0.113155 & 0.096075 \\
\hline Bl.11 & 0.785075 & 0.094684 & 0.202701 & -0.079239 \\
\hline B2.1 & 0.674811 & 0.370215 & 0.085188 & 0.053419 \\
\hline B2.6 & 0.642675 & 0.179771 & 0.256253 & -0.036472 \\
\hline B2.3 & 0.411790 & 0.508889 & 0.135909 & 0.267717 \\
\hline B2.4 & 0.288722 & 0.557468 & 0.078171 & 0.322003 \\
\hline B2.7 & 0.320761 & 0.641714 & 0.311717 & -0.044021 \\
\hline B2.8 & 0.214664 & 0.565997 & 0.410174 & 0.180533 \\
\hline B2.9 & 0.038387 & 0.774267 & 0.192980 & 0.026282 \\
\hline B2.10 & 0.029069 & 0.795758 & 0.221899 & 0.110927 \\
\hline B2.11 & 0.051881 & 0.575880 & 0.465613 & 0.259511 \\
\hline B3.8 & 0.378119 & 0.179387 & 0.701020 & 0.135878 \\
\hline B3.9 & 0.162212 & 0.265756 & 0.721058 & 0.021162 \\
\hline B3.10 & 0.166459 & 0.150129 & 0.674682 & 0.239993 \\
\hline B3.11 & 0.084595 & 0.284588 & 0.693772 & 0.341932 \\
\hline B2.2 & 0.221007 & 0.218794 & 0.327017 & 0.522901 \\
\hline B3.1 & 0.126195 & -0.251871 & 0.193905 & 0.625636 \\
\hline B3.2 & -0.132663 & 0.366867 & 0.082235 & 0.726596 \\
\hline B3.3 & -0.265838 & 0.417589 & 0.070479 & 0.657064 \\
\hline B3.7 & -0.399571 & -0.058184 & 0.091296 & 0.549377 \\
\hline
\end{tabular}




\begin{tabular}{|c|c|c|c|}
\hline & Factor 5 & Factor 6 & Factor 7 \\
\hline TLETIS & Low financial inclusion & Banking and savings behaviour & Responsible spending behaviour \\
\hline B4.1 & -0.687865 & -0.155167 & -0.220569 \\
\hline B4.6 & -0.673299 & 0.133217 & 0.071308 \\
\hline B4.9 & -0.777118 & 0.070711 & -0.067932 \\
\hline B5.3 & -0.806936 & -0.082536 & 0.041804 \\
\hline B5.4 & -0.629941 & -0.087446 & -0.265425 \\
\hline B4.2 & 0.140306 & 0.665910 & 0.148780 \\
\hline B4.3 & 0.162529 & 0.613102 & 0.096055 \\
\hline B4.8 & 0.074677 & 0.751249 & 0.164104 \\
\hline B5.1 & -0.100209 & 0.689737 & 0.281545 \\
\hline B5.2 & 0.284643 & 0.682116 & 0.179390 \\
\hline B5.5 & -0.205757 & 0.702787 & 0.195070 \\
\hline B5.6 & 0.052484 & 0.617420 & 0.281954 \\
\hline B5.7 & -0.377614 & 0.556671 & 0.146370 \\
\hline B5.8 & -0.134015 & 0.525489 & 0.425193 \\
\hline B5.9 & -0.230364 & 0.280217 & 0.615403 \\
\hline B5.10 & -0.174060 & 0.225307 & 0.531378 \\
\hline B5.11 & 0.097689 & 0.381886 & 0.525133 \\
\hline B5.12 & 0.049137 & 0.347141 & 0.580806 \\
\hline B5.13 & -0.000351 & 0.130583 & 0.681943 \\
\hline B5.14 & 0.204318 & 0.096754 & 0.744120 \\
\hline B5.15 & 0.235479 & 0.149705 & 0.696599 \\
\hline B5.16 & 0.099952 & 0.297860 & 0.720476 \\
\hline
\end{tabular}

Source: Calculated from survey EFA results - intervening and dependent variables. 